\title{
Pathogenic Microbes from Unprotected Landfills Pose Health Hazards with Potentials of Disease Outbreaks in Nigeria
}

\author{
Eucharia Ezenwanyi Nmema ${ }^{1 *}$ \\ ${ }^{1}$ Department of Biological Sciences, Ondo State University of Science and Technology, P.M.B. 353, \\ Okitipupa 350002, Ondo State, Nigeria. \\ Author's contribution \\ The sole author designed, analyzed and interpreted and prepared the manuscript. \\ Article Information \\ DOI: $10.9734 / A R R B / 2017 / 32766$ \\ Editor(s): \\ (1) Paola Angelini, Department of Applied Biology, University of Perugia, Perugia, Italy. \\ (2) George Perry, Dean and Professor of Biology, University of Texas at San Antonio, USA. \\ Reviewers: \\ (1) Wahome Caroline Nyawira, Kenyatta University, Kenya. \\ (2) Bela Nabar, Smt CHM College, Mumbai University, India. \\ (3) Ionica Mihaela lancu, Banat University of Agronomical Sciences and Veterinary Medicine, Timisoara, Romania. \\ Complete Peer review History: http://www.sciencedomain.org/review-history/19224
}

Original Research Article

Received $14^{\text {th }}$ March 2017

Accepted $27^{\text {th }}$ April 2017

Published 27 $7^{\text {th }}$ May 2017

\section{ABSTRACT}

Aims: This study assessed some health hazards associated with landfills and waste dumping by comparing pathogenic microbes from Olusosun Landfill and a control field in Lagos, Nigeria.

Study Design: A comparative, investigative survey.

Place and Duration of Study: Biotechnology Laboratory, Federal Institute of Industrial Research, Oshodi, Lagos, between August 2015 and February 2016.

Methodology: Soil samples were collected from the superficial layers $(1-20 \mathrm{~cm})$ of alfisol at the landfill and a field located about 1000 meters from the dumpsite. Coliform counts, identification of bacteria and susceptibility to antibiotics were carried out. One-way Analysis of variance (ANOVA) was used for statistical analysis, with level of significance at 0.05 .

Results: Coliform counts were $51 \times 10^{5}$ and $38 \times 10^{5} \mathrm{CFU} \mathrm{g}^{-1}$ dry soil for landfill soil and field soils respectively. Species of Gram-negative bacteria (16) and Gram-positive bacteria (20) found in landfill soil outnumbered Gram-negative bacteria (7) and Gram-positive bacteria (10) found in field soil. potential pathogenic species isolated from landfill soil were Enterobacter, Escherichia coli, 
Klebsiella, Pseudomonas aeruginosa, Clostridium, Corynebacterium, Micrococcus, and Staphylococcus, outnumbering pathogenic species in field soil. $56.3 \%$ of Gram-negative bacteria and $55.0 \%$ of Gram-positive bacteria from landfill soil gave Multiple Antibiotic Resistance (MAR) Index above 0.5. Significant differences $(P<0.05)$ existed between the MAR Index of Gramnegative bacteria in landfill and field soils, but no significant differences $(P=0.6348)$ between Grampositive bacteria in landfill and field soils.

Conclusion: The findings reveal that pathogenic species of bacteria inhabiting landfill soil are more diverse and numerous than in field soil. The presence of coliforms in landfill soil is an indication of faecal contamination. This implies that the presence of landfills, though needful, poses health hazards which cannot be overlooked. The author emphasises the importance of sterilizing waste before dumping, citing landfills far from residential areas, water bodies and farms, as well as provision of potable water.

Keywords: Landfill; coliforms; pathogenic bacteria; MAR index; Nigeria.

\section{INTRODUCTION}

In Nigeria, solid waste generated from domestic, industrial and commercial activities are collected by sanitation teams and dumped in officially designated landfills in the urban centres. However, most surburbs and villages do not have landfills where waste can be disposed, but people create dumpsites anywhere it is convenient, including major roadsides, markets, and residential areas. Indiscriminate dumping of untreated waste is usually overlooked by the authorities who lack governmental will to control it. Due to lack of potable water, people in the localities rely on surface waters and untreated ground water for drinking, domestic, industrial purposes. The likelihood of chemical and microbial contaminants being carried from dumpsites to water bodies creates an unsanitary situation with the possibility of health hazards posed by environmental contamination $[1,2]$.

Though the soil is usually home to a variety of microbial genera including beneficial and potentially pathogenic species $[3,4]$, soils around landfills and dumpsites are prone to greater contamination with harmful materials and microbes from wastes. Most of the refuse in landfills and dumpsites are untreated and may contain organic and inorganic materials which are harmful. Some of the wastes are unsterilized materials from microbiology laboratories, hospitals and homes containing pathogenic microbes.

Bacteria genera of pathogenic importance such as Salmonella, Shigella, Campylobacter and Escherichia coli, Pseudomonas and Vibrio cholerae have been isolated from soils around dumpsites. Water bodies at nearby to the dumpsites also yielded the same kind of microbes, indicating that pathogens from dumpsites soils can percolate into nearby water bodies. The isolates showed multi-drug resistance to Gentamicin, Chloramphenicol and Amikacin [2].

Another study analysing leachate from Awotan dumpsite at Ibadan isolated 26 bacteria belonging to seven different genera, including potential pathogens such as E. coli, Klebsiella pneumoniae, Staphylococcus aureus and Pseudomonas species. These exhibited high tolerance to antibiotics like gentamicin $(100 \%)$, ampiclox (100\%), septrin (75\%), streptomycin (75\%), ciprofloxacin (50\%) [5].

Olusosun landfill is located in Lagos Mainland. Around 1000 homes exist at the site in shanty towns, occupied by residents who work at the dump, scavenging for scraps to sell for a living. Olusosun landfill, once on the outskirts of the populated area, is now closely surrounded by commercial and residential areas due to uncontrolled expansion [6,7]. The proximity of this massive landfill to homes, commercial areas and groundwater speaks volumes about the efficiency of town planning departments in the country, as well as agencies saddled with sanitation programs. Having to live close to, or scavenge for a living in dumpsites exposes people to health hazards which result from contact with, aerosol inhalation or ingestion of contaminated materials.

It is a common practice in Nigeria to dump waste materials in open places close to homes and domestic water sources. This has long been connected to environmental pollution and health problems. The present research was conducted to investigate possible health hazards arising 
from bacterial contamination due to the proximity of landfills and ubiquitous presence of dumpsites in the localities.

\section{MATERIALS AND METHODS}

\subsection{Soil Sample Collection}

Soil sub-samples (10) were randomly collected from the superficial layers $(1-20 \mathrm{~cm})$ of alfisol at the landfill and pooled to form composite sample. Soil samples were also collected from a field located about 1000 meters away from the landfill. The samples were stored in sterile cellophane bags and taken to the Biotechnology Laboratory, Federal Institute of Industrial Research, Oshodi, Lagos, for microbiological within 8 hours.

\subsection{Coliform Count}

Ten $\mathrm{g}$ of each soil sample were added to $95 \mathrm{~mL}$ of $0.1 \%(\mathrm{w} / \mathrm{v})$ solution of sodium pyrophosphate. After homogenization for $30 \mathrm{~min}$, this solution was decimally diluted $\left(10^{-1}\right.$ to $\left.10^{-7}\right)$. Aliquots of the resulting solutions were inoculated on MacConkey agar for coliform counts. After incubation at $30^{\circ} \mathrm{C}$, for up to 10 days, the colonies in each plate were counted. Counts were calculated as $y=\log (x+1)$, where $x$ was the number of CFU $g^{-1}$ dry soil.

\subsection{Identification of Microorganisms}

An aliquot of $0.1 \mathrm{ml}$ of each dilution was taken and spread evenly over the surface of Nutrient agar and MacConkey agar. Plates were incubated overnight at $30^{\circ} \mathrm{C}$. Suspected colonies were sub-cultured on fresh medium to produce discrete colonies for the identification tests. Biochemical tests were performed using conventional phenotypic methods $[8,9,10]$. Gram staining, motility tests, starch, gelatin and casein hydrolysis were performed for genus identification. Biochemical tests for catalase, oxidase, indole production, urease, Methyl Red and Voges Proskauer tests, Nitrate $\left(\mathrm{NO}_{3}\right)$ reduction, and utilization of different carbon sources such as such as citrate, starch, glucose, sucrose, xylose, lactose, mannitol, maltose, raffinose, arabinose, sorbitol, fructose, and salicin were used to establish possible species identity. The biochemical tests were performed by the conventional phenotypic method.

\subsection{Antimicrobial Susceptibility Testing}

Susceptibility to antibiotics was tested by discdiffusion method [11]. Gram-negative bacteria were screened against co-trimoxazole $30 \mu \mathrm{g}$, chloramphenicol $30 \mu \mathrm{g}$, sparfloxacin $10 \mu \mathrm{g}$, ciprofloxacin $10 \mu \mathrm{g}$, ofloxacin $10 \mu \mathrm{g}$, perfloxacin $30 \mu \mathrm{g}$, amoxicillin $30 \mu \mathrm{g}$, augmentin $30 \mu \mathrm{g}$, gentamicin $10 \mu \mathrm{g}$, streptomycin $30 \mu \mathrm{g}$. Grampositive bacteria were screened against perfloxacin $10 \mu \mathrm{g}$, gentamicin $10 \mu \mathrm{g}$, ampiclox 30 $\mu \mathrm{g}$, zinnacef $20 \mu \mathrm{g}$, amoxicillin $30 \mu \mathrm{g}$, rosephin $25 \mu \mathrm{g}$, ciprofloxacin $10 \mu \mathrm{g}$, streptomycin $30 \mu \mathrm{g}$, co-trimoxazole $30 \mu \mathrm{g}$, erythromycin $10 \mu \mathrm{g}$. Antimicrobial susceptibility tests were performed for all isolates according to the criteria of the Clinical and Laboratory Standards Institute [12]. Bacterial suspensions were prepared, adjusted to the $0.5 \mathrm{McF}$ arland Standards, and inoculated onto Mueller-Hinton agar (Oxoid) by surface swabbing. Using sterile forceps, the antibioticcontaining discs were placed aseptically on the inoculated plates and left on the table for 1 hour for proper diffusion to occur. The plates were incubated in an inverted position, at $35^{\circ} \mathrm{C}$ for 16 18 hours and thereafter examined for clear zones of inhibition. Inhibition zone diameters (IZD) around each antibiotic disk (if any), were measured using a transparent ruler, and recorded in millimeters $(\mathrm{mm})$. A standardized table was used to determine if the bacterium was "Resistant", "Intermediate" or "Sensitive".

\section{RESULTS AND DISCUSSION}

\subsection{Coliform Counts}

The coliform count in the present study was $51 \times 10^{5}$ and $38 \times 10^{5}$ (CFU g ${ }^{-1}$ dry soil) for landfill soil and field soil respectively. This situation is fraught with the danger of flood waters carrying these coliforms into nearby surface and ground waters. The microbial quality of portable water should not exceed limits specified in the water quality guideline [13]. However, the microbial quality of water in several rural Nigerian communities has been reported to be poor, unsafe and not acceptable for human consumption $[1,2]$, a situation which agrees with the findings of the present study.

\subsection{Pathogenic Bacteria Isolated from landfill Soil and Field Soil Samples}

Gram negative bacteria isolated from the landfill soil included the coilforms: Citrobacter, Enterobacter, Escherichia coli, Klebsiella, Raoultella planticola and Serratia. Also isolated were Alcaligenes, Acinetobacter, Proteus, Flavobacteria and Pseudomonas species. Gram 
negative bacteria isolated from the field soil included the coliforms: Enterobacter, Klebsiella and Serratia. Also isolated were Alcaligenes, Acinetobacter and Flavobacterium species (Table 1).

Gram-positive bacteria isolated from landfill soil included Bacillus species, Clostridium species, Corynebacterium species, Micrococcus species and Staphylococcus aureus. Gram-positive bacteria isolated from field soil, included Bacillus species, Corynebacterium species, and Micrococcus species (Table 2).

\subsection{Multiple Antibiotic Resistance (MAR) Index of Bacteria Isolated from Landfill Soil and Field Soil}

Of Gram-negative bacteria isolates, $56.3 \%$ from landfill soil, and $14.3 \%$ from field soil gave MAR Index above 0.5. (Table 1) Of the Gram-positive bacteria isolates, $55.0 \%$ from landfill soil and $50 \%$ from field soil gave MAR Index above 0.5. (Table 2).

When Analysis of Variance was employed, there were significant differences $(P<0.05)$ between the MAR Index of Gram-negative bacteria in landfill and field soils. However, there were no significant differences $(P=0.6348)$ between the multiple antibiotic resistance (MAR) Index of Gram-positive bacteria in landfill and field soils.

Analysis of the soil obtained from Olusosun landfill revealed the presence of Gram negative bacteria species such as Alcaligenes, Acinetobacter, Citrobacter, Enterobacter, Escherichia coli, Flavobacterium, Klebsiella, Proteus, Pseudomonas aeruginosa, P. putida and Serratia species. The potential pathogenicity of the isolates cannot be denied as these bacteria could be infectious, opportunistic or emerging pathogens. The presence of coliform bacilli among the landfill isolates is a pointer to the level of faecal contamination which is possible to water bodies around the landfill. Gram positive bacteria isolated from the landfill soil included potential pathogens such as Clostridium species, Corynebacterium species, Micrococcus species, and Staphylococcus species, and Bacillus species.

A high MAR Index was exhibited by landfill soil isolates. $56.3 \%$ of Gram-negative bacteria and $55.0 \%$ of Gram-positive bacteria from landfill soil gave MAR Index above 0.5 . This indicates that isolates from the landfill probably originated from environments where antibiotics are frequently used or abused. This implies that some of the waste come from homes, hostels or hospitals, and may include unsterilized human and animal excreta, and materials contaminated by them.

Relative to the field soil, landfill soil yielded bacteria with higher species diversity, pathogenicity and MAR index. This is evidence that landfills in the country receive untreated wastes which support and encourage the growth of diverse kinds of microbes, many of which are pathogenic.

Table 1. Multiple Antibiotic Resistance (MAR) index of gram-negative bacteria isolated from landfill soil and field soil

\begin{tabular}{llll}
\hline Landfill soil isolate & MAR index & Field soil isolate & MAR index \\
\hline Alcaligenes eutrophus & 1 & Alcaligenes latus & 0.4 \\
A. faecalis & 0.4 & Acinetobacter mallei & 0.6 \\
Acinetobacter anitratus & 0.1 & A. iwoffi & 1 \\
Citrobacter diversus & 0 & Enterobacter intermedius & 0.5 \\
Enterobacter aerogenes & 0.8 & Flavobacterium aquantile & 0.3 \\
E. agglomerans & 0.5 & Klebsiella terrigena & 0.3 \\
E. cloacae & 0.6 & Serratia rubidaea & 0.1 \\
Escherichia coli & 0.4 & & \\
Flavobacterium gleum & 0.9 & & \\
F. rigense & 0.6 & & \\
Klebsiella pneumoniae & 0.6 & & \\
Proteus vulgaris & 0.1 & & \\
Pseudomonas aeruginosa & 0.9 & & \\
P. putida & 0.6 & & \\
Raoultella planticola & 0.8 & & \\
Serratia liquifasciens & 0.1 & & \\
\end{tabular}


Table 2. Multiple Antibiotic Resistance (MAR) index of gram-positive bacteria isolated from landfill soil and field soil

\begin{tabular}{llll}
\hline Landfill soil isolate & MAR index & Field soil isolate & MAR index \\
\hline Bacillus brevis & 0.6 & Bacillus brevis & 0.1 \\
${ }^{*} B$. cereus & 0.5 & B. fastidiosus & 0.7 \\
${ }^{*} B$. cereus & 0.8 & ${ }^{*} B$. licheniformis & 0.7 \\
B. circulans & 0.8 & B. polymyxa & 0.5 \\
B. coagulans & 0.6 & ${ }^{*} B$. sphaericus & 0.7 \\
${ }^{*}$ B. laterosporus & 0.3 & ${ }^{*} B$. subtilis & 0.3 \\
${ }^{*}$ B. licheniformis & 0.3 & Corynebacterium pilosum & 0.1 \\
B. mycoides & 0.2 & C. fascians & 0.6 \\
B. pastearii & 1 & Micrococcus kristinae & 0.5 \\
B. polymyxa & 0.7 & M. candidus & 0.6 \\
${ }^{*}$ B. subtilis & 0.8 & & \\
B. thuringensis & 0.8 & & \\
Clostridium tertium & 0.9 & & \\
Corynebacterium kutscheria & 0.6 & & \\
C. pilosum & 0.2 & & \\
C. striatum & 0.3 & & \\
Micrococcus roseus & 0.2 & & \\
M. luteus & 0.4 & & \\
M. varians & 0.4 & & \\
Staphylococcus aureus & 0.7 & & \\
\hline
\end{tabular}

Enterobacter aerogenes (MAR index 0.8), E. agglomerans (MAR index 0.5), and E. cloacae (MAR index 0.6), were among the Gram negative bacteria isolated from the landfill soil. $E$. aerogenes and $E$. cloacae are important nosocomial pathogens responsible for various infections, including bacteremia, lower respiratory tract infections, urinary tract infections, lower respiratory tract infections, endocarditis, CNS infections and ophthalmic infections. These infections can necessitate prolonged hospitalization, complicated diagnostic procedures and expensive antimicrobial therapy, often complicated by antimicrobial resistance [14].

Flavobacterium gleum and $F$. rigense were isolated from the landfill soil and showed high MAR Index of 0.9 and 0.6 respectively. Flavobacteria are found in soil and freshwater in a variety of environments and are known for their pathogenicity in animals, particularly fish. Pathogenic and opportunistic infections caused by Flavobacteria in fish, birds, dogs and humans are severe and difficult to treat. Flavobacterium infections in fish has resulted in large loses in fish yields [15].

Raoultella planticola (formally Klebsiella species), an aggressive and abundant soil bacteria, was among the Gram negative bacteria isolated from field soil. Medically, it has been isolated in two cases of septicaemia, and complicated at least one case of severe pancreatitis, as well as an agent of pneumonia, UTI, soft tissue infection, gastroenteritis, bacteremia, conjunctivitis and septic shock $[16,17]$.

Bacillus species were dominant among the Gram positive isolates from both the landfill soil and field soil. Bacillus species are rarely implicated in actual infections, and are more frequently isolated as culture contaminants. However, few species have been implicated in serious infections, including $B$. cereus, $B$. subtilis, $B$. sphaericus, B. alvei, B. laterosporus, $B$. licheniformis, $B$. megaterium and $B$. pumilus. Five of these clinically important Bacillus species were isolated in the present study [18].

The pathogenic bacteria found in this study exhibited multiple resistance to mainstream antibiotics which implies that people in these localities are exposed to MAR microbes which may cause diseases or epidemics that are difficult to treat. The non-pathogenic isolates exhibited high MAR profile as well as the pathogens, leading to the conclusion that they also contribute to pathogenicity, since they can transfer resistance determinants to the pathogenic species. 


\section{CONCLUSION}

In Nigerian cities, surburbs and villages, surface waters and ground waters are still major sources of water for drinking, domestic and agricultural purposes. Many water bodies are not protected, and most people use water without sterilization. If potential pathogens with high MAR Index are carried from the numerous dumpsites into unprotected water bodies, this raises questions about health safety of the local populations. According to World Health Organization (WHO) Guidelines for Drinking-water Quality (2011), securing the microbial safety of drinking water supplies is based on the use of multiple barriers, including, among others, the protection of water resources, with emphasis on preventing or reducing the entry of pathogens into water sources. Failure to ensure drinking water safety may expose the surrounding communities to the risk of outbreaks of intestinal and other infectious diseases. Outbreaks of waterborne diseases are particularly to be avoided because of their capacity to result in the simultaneous infection of a large number of persons [19]. To protect the environment and water resources in developing countries, a system for proper dumpsite selection should be developed. Regulation of refuse dumping as well as provision of potable water will go a long way to protect individuals from disease outbreaks due to use of contaminated water.

\section{COMPETING INTERESTS}

Author has declared that no competing interests exist.

\section{REFERENCES}

1. Ediagbonya TF, Nmema EE, Nwachukwu PC, Teniola OD. Identification and quantification of heavy metals, anions and coliforms in water bodies using enrichment factors. Journal of Environmental and Analytical Chemistry. 2015;2(4):146.

DOI: 10.4172/2380-2391.1000146

2. Ikpeme E, Nfongeh J, Enyi-Idoh K, Eja ME, Etim L. Antibiotic susceptibility profiles of enteric bacterial isolates from dumpsite utisols and water sources in a rural community in Cross River State, Southern Nigeria. Nature and Science. 2011;9(5): 46-50.

3. Nwinyi OC, Alade A, Leo-Akpan IR, Oladele BO. Isolation and characterization of bacterial diversity from soils supplemented with electrical transformer fluids. South Asian Journal of Experimental Biology. 2011;1(2):107-113.

ISSN: 2230-9799.

Available:http:/www.sajeb.org

4. Olawale AK, Akintobi OA. Biodegradation of glyphosate pesticide by bacreria isolated from agricultural soil. Report and Opinion. 2011;3(1):124-128.

ISSN: 9873.

Available:http:/www.sciencepub.net.

5. Sulaimon AM, Akinwotu OO, Amoo OT. Resistance of bacteria isolated from awotan dumpsite leachate to heavy metals and selected antibiotics. International Journal of Research in Pharmacy and Biosciences. 2015;2(9):8-17. ISSN 2394-5893 (Online).

6. The Big Picture/Environment/The Observer. Guardian; 2008-03-23.

7. Olusosun: Intriguing ways of seeking wealth in refuse heaps. Vanguardngr.com. 2012-06-27.

8. Frankland JC, Latter PM, Poskitt JM. A laboratory guide to soil microbiology: Some general principles and practice. Merlewood Research and Development. 1995;79

9. Cowan ST, Steel KJ. Manual for the identification of medical bacteria. Barrow GI, Feltham RKA. $3^{\text {rd }}$ ed. Cambridge University Press; 1993.

10. Bergey DH. Bergey's manual of determinative bacteriology. American Society of Microbiology. Bergey DH, 18601937; Breed RS, 1977-1956. Baltimore, Williams \& Wilkins Co; 1957.

11. Bauer AW, Kirby WMM, Sherris JC, Turck M. Antibiotic susceptibility testing by a standardized single disk method. American Journal of Pathology. 1966;45:493-6.

12. Clinical Laboratory Standards Institute (CLSI) M100-S20. Performance standards for antimicrobial disk susceptibility tests. Informal Supplement; 2010.

13. APHA. Standard methods for the examination of water and wastewater. $\left(20^{\text {th }}\right.$ ed) Washington: American Public Health Association. 1998;1220.

14. Fraser SL. Enterobacter infections. In: Infectious Diseases. Bronze MS. ed. Medscape; 2016.

15. Bernardet JF, Nakagawa Y. An Flavobacteriaceae. The Prokaryotes. Dworkin M, Falkow S, Rosenberg E, Schleifer $\mathrm{KH}$, Stackebrandt $\mathrm{E}$, editors. 2006;7. 
16. Westbrook GL, O'Hara CM, Roman SB, Miller JM. Incidence and identification of Klebsiella planticola in clinical isolates with emphasis on newborns. Journal of Clinical Microbiology. 2000;38(4):1495-7.

PMC: 86473. PMID: 10747132.

17. Alves MS, Riley LW, Moreira BM. A case of severe pancreatitis complicated by Raoultella planticola infection. Journal of Medical Microbiology. 2007;56(Pt 5):696-8.
DOI: $10.1099 / j m m \cdot 0.46889-0$

PMID: 17446297.

18. Tuazon CU. Bacillus species. In: Infectious disease and antimicrobial agents. E-Sun Technologies, Inc; 2010-2017.

19. WHO. Guidelines for drinking-water quality. $4^{\text {th }}$ ed. World Health Organization; 2011.

ISBN: 9789241548151.

(c) 2017 Nmema; This is an Open Access article distributed under the terms of the Creative Commons Attribution License (http://creativecommons.org/licenses/by/4.0), which permits unrestricted use, distribution, and reproduction in any medium, provided the original work is properly cited.

Peer-review history:

The peer review history for this paper can be accessed here: http://sciencedomain.org/review-history/19224 